\title{
KOMPETENSI PENDIDIK AGAMA DALAM SURAT AL-'ALAQ PERSPEKTIF TAFSIR AL-MISBAH KARYA MUHAMMAD QURAISH SHIHAB
}

\section{Dewi Ayu, Taufik Abdillah Syukur}

Sekolah Tinggi Agama Islam ALHIKMAH Jakarta

dewiayu.62df@gmail.com, taufik.a@uinjkt.ac.id

\section{Abstract}

The purpose of this study was to determine the Competence of Religious Educators based on Q.S. Al-'Alaq's perspective on the Tafsir al-Misbah by M. Quraish Shihab. Research that uses the Pure library research method. The results of this study obtained data that the competence of religious educators in the Q.S. al-'Alaq perspective of Tafsir Al-Misbah by M. Quraish Shihab consists of pedagogic competence, personality competence, social competence, and professional competence. This conclusion supports Article 10 of the Law of the Republic of Indonesia number 14 of 2005 concerning teacher competencies.

Keywords: Competence, Religious Educator, Surat al-'Alaq, Tafsir al-Misbah 


\section{Abstrak}

Tujuan penelitian ini adalah untuk mengetahui Kompetensi Pendidik Agama berdasarkan Q.S. Al-Alaq perspektif tafsir alMisbah karya M. Quraish Shihab. Penelitian yang menggunakan metode Pure library research. Hasil penelitian ini memperoleh data bahwa kompetensi pendidik agama dalam Q.S. al-'Alaq perspektif tafsir al-Misbah karya M. Quraish Shihab terdiri dari kompetensi pedagogik, kompetensi kepribadian, kompetensi sosial, dan kompetensi profesional. Kesimpulan ini mendukung Pasal 10 Undang-Undang Republik Indonesia nomor 14 tahun 2005 tentang kompetensi guru.

Kata Kunci: Kompetensi, Pendidik Agama, Surat al-'Alaq, Tafsir al-Misbah 


\section{A. PENDAHULUAN}

$\mathrm{P}$ endidikan di Indonesia telah mengalami banyak perubahan guna memenuhi kebutuhan di masyarakat. Perubahan tersebut dilakukan agar Indonesia mampu menghasilkan generasi muda yang berprestasi tidak hanya di Indonesia saja namum generasi muda yang mampu pula bersaing di era globalisasi saat ini khususnya di era Masyarakat Ekonomi Asea (MEA).

Salah satu perubahan yang dilakukan oleh Pemerintah dan Dinas Pendidikan Indonesia adalah perubahan kurikulum, mulai dari Kurikulum Tingkat Satuan Pendidikan (KTSP) dimana sekolah bebas mengembangkan kurikulum sesuai kondisi di tandai munculnya kelas berstandar international, menjadi Kurikulum 2013 (K13) yang mengutamakan pengembangan konsep kompetensi inti sebagai indikator horizontal, ditandai sejumlah mata pelajaran dikurangi atau di integrasi. perubahan kurikulum ini dilakukan untuk meningkatkan kualitas dari pendidikan di indonesia.

Penggunaan teknologi ikut andil dalam mempermudah kegiatan belajar mengajar. Dewasa ini sudah banyak sekolah mulai dari sekolah negeri sampai swasta yang menggunakan teknologi sebagai alat bantu tambahan dalam proses belajar mengajar. Hal tersebut ternyata banyak memberi sumbangsi pada mutu pendidikan di setiap sekolah. Bahkan di beberapa sekolah menggunakan pengembangan teknologi sebagai alat wajib dalam pengajaran.

Namun berdasarkan Survey yang dilakukan oleh OECD (Organisation for Economic Co-operation and Development) pada tahun 2015 indonesia meduduki peringkat 69 dari 79 negara. Indonesia menepati peringkat 10 terbawah, peringkat pendidikan indonesiaa jauh dibawah Malaysia dan Thailand. Hal tersebut menunjukan bahwa kualitas dan mutu pendidikan di Indonesia masih kurang maksimal. Pada kenyataannya masih banyak lulusan yang masih kompeten dibidangnya dan sulit bersaing di dunia pekerjaan.

Merosotnya kualitas pendidikan di Indonesia tentunya tidak terlepas dari merosotnya kualitas yang dimiliki oleh para pendidik. 
Walau demikian, merosotnya kualitas pendidikan di Indonesia juga tidak boleh sepenuhnya menyalahkan para pendidik. Karena pendidik hanyalah salah satu komponen saja dalam proses pendidikan. Selain pendidik, masih banyak faktor lain yang ikut menentukan kualitas pendidikan, seperti sistem pendidikan yang diterapkan bangsa, perhatian pemerintah dan bangsa terhadap pendidikan itu sendiri, penyaluran dana, pola pengelolaan dan faktor lain yang secara inheren sebagai bagian dari proses pendidikan itu sendiri.

Guru dalam pendidikan Islam juga merupakan figur yang sangat penting, begitu pentingnya pendidik sehingga menempatkan mereka setingkat di bawah kedudukan para Nabi dan Rasul. Maka dalam pendidikan Islam, pendidik adalah komponen yang sangat penting dalam sistem kependidikan, karena ia yang mengantarkan peserta didik pada tujuan yang telah ditentukan, bersamakomponen yang lain terkait dan lebih bersifat komprehensif. Peranan pendidik dalam menunjang keberhasilan pendidikan sangat penting. Karena itu, upaya apa pun yang diselenggarakan untuk meningkatkan mutu pendidikan harus bersentuhan dengan sumber daya guru.

Menghadapi kenyataan seperti di atas tentunya pendidik dituntut untuk senantiasa meningkatkan kompetensinya. Berdasarkan proses interaksi belajar mengajar, guru memiliki peran yang sangat penting dalam memberikan pelajaran kepada siswa. Dalam mentransfer pengetahuan kepada siswa diperlukan pengetahuan, kecakapan dan keterampilan sebagai guru. Sebab tanpa ini semua tidak mungkin proses interaksi tersebut dapat berjalan secara kondusif. Oleh karenanya di sinilah kompetensi dalam arti kemampuan, mutlak diperlukan guru dalam melaksanakan tugasnya sebagai pendidik. ${ }^{1}$

Di antara kompetensi lain yang harus dimiliki guru adalah pengendali dan pengarah proses serta pembimbing arah perkembangan dan pertumbuhan manusia didik, serta memahami kebutuhan perkembangan dan pertumbuhan manusia didik bagi

1 Syaiful Bahri Djamarah, Prestasi Belajar dan Kompetensi Guru, (Surabaya : Usaha Nasional, 1994), hal. 32. 
kehidupannya di masa depan dan pendidik harus memahami dan pandai menggunakan berbagai macam metode yang berdaya guna dalam penerapan proses kependidikan sesuai dengan tuntutan kebutuhan tingkat perkembangan dan pertumbuhan mereka yang berpusat pada kemampuan kognitif, konatif (kemauan) dan emosional atau afektif serta psikomotorik manusia didik dalam kerangka fitrah masing-masing. ${ }^{2}$

Selanjutnya dalam Undang-undang Republik Indonesia nomor 14 tahun 2005 tentang Guru dan Dosen, bab IV telah dijelaskan tentang kompetensi guru, pasal 10 yang berbunyi :

1. bahwa kompentensi guru yang dimaksud dalam pasal 8 meliputi kompetensi pedagogik, kompetensi keperibadian, kompetensi sosial, dan kompetensi profesional yang diperoleh melalui pendidikan profesi.

2. Ketentuan lebih lanjut mengenai kompetensi guru sebagaimana dimaksud pada ayat (1) diatur dengan Peraturan Pemerintah. ${ }^{3}$

Penjelasan dari pasal 10 ayat (1) bahwa yang dimaksud dengan kompetensi pedagogik adalah kemampuan mengelola pembelajaran peserta didik. Yang dimaksud dengan kompetensi kepribadian adalah kemampuan kepribadian yang mantap, berakhlak mulia, arif dan berwibawa serta menjadi teladan peserta didik.

Karena begitu besarnya peran guru dalam pendidikan, sehingga Bapak Abdul Malik Fadjar yang menyatakan dengan tegas bahwa "guru yang utama" (Republika, 10 Februari 2003). Belajar bisa dilakukan dimana saja, tetapi guru tidak dapat digantikan oleh siapa atau alat apapun jua. Untuk membangun pendidikan yang bermutu, yang paling penting bukan membangun gedung sekolah atau sarana, melainkan harus dengan upaya peningkatan proses pengajaran dan pembelajaran yang berkualitas, yakni proses pembelajaran yang menyenangkan, mengasyikkan, dan mencerdaskan. Hal ini bisa dilakukan oleh guru yang bermutu. ${ }^{4}$

\footnotetext{
2 M. Arifin, Ilmu Pendidikan Islam, (Jakarta : Bumi Aksara, 1996), hal. 143.

3 Undang-Undang Republik Indonesia Tentang Guru dan Dosen, (Yogyakarta: Pustaka Pelajar, 2006), hal. 5.

4 Suparlan, Guru Sebagai Profesi, (Yogyakarta : HIKAYAT Publishing, 2006), hal. 10 .
} 
Selanjutnya bagaimana kemudian ketika macam-macam kompetensi di atas, dihubungkan dengan al-Qur'an yang menjadi salah satu sumber ilmu pengetahuan dan telah banyak memberikan inspirasi edukatif, disebabkan pengembangan demikian diperlukan sebagai kerangka dasar dalam upaya membangun sistem pendidikan seutuhnya, dengan cara mengintrodusir konsep-konsep al-Qur'an tentang kependidikan, misalkan ayat-ayat yang menjelaskan tentang kompetensi guru, seperti yang tertera dalam Surat Al-Alaq Ayat 1-5.

Surah al-Alaq dimulai dengan perintah untuk membaca, menelaah, meneliti dengan syarat semua hal tersebut harus dilakukan dengan atau demi nama Tuhan yang selalu memelihara dan membimbing manusia. Kemudian menjelaskan tentang adanya potensi yang dimiliki manusia, yaitu sebagai makhluk sosial yang selalu membutuhkan bantuan sesamanya. Selanjutnya menjelaskan pentingnya kesadaran akan kehadiran Tuhan di alam raya ini serta pengetahuan-Nya akan gerak langkah serta detakdetik hati manusia, akan mengantarkan kepada kesadaran akan jati diri manusia serta peran yang harus diembannya dalam kehidupan ini.

Tafsir Al-Mishbah yang ditulis oleh M. Quraish Shihab berjumlah XV volume, mencakup keseluruhan isi al-Qur'an sebanyak 30 juz. Kitab ini pertama kali diterbitkan oleh Penerbit Lentera Hati, Jakarta, pada 2000. Kemudian dicetak lagi untuk kedua kalinya pada 2004.

M. Quraish Shihab termasuk ulama yang juga terjun langsung di dunia pendidikan, ini terlihat dari pengalamannya yang menjabat di berbagai jabatan akademis. Seperti setelah pulang menyelesaikan pendidikan magister, ia membantu ayahnya membina perguruan tinggi di Ujung pandang. Quraish Shihab dipercaya untuk menjabat Wakil Rektor bidang Akademis dan Kemahasiswaan pada IAIN Alaudin. Juga terpilih sebagai Koordinator Perguruan Tinggi Swasta (Wilayah VII Indonesia Bagian Timur).

Tujuan penelitian ini adalah untuk mengetahui kompetensi 
pendidik agama dalam Q.S Al-Alaq perspektif tafsir Al-Misbah karya M. Quraish Shihab. Metodelogi penelitian dalam penelitian ini adalah bersifat deskriptif analisis dengan menggunakan teknik analisis deskriptif kajian ini melalui studi kepustakaan (Library Research), yaitu dengan membaca, meneliti, dan mengkaji bukubuku, hasil tulisan yang berhubungan dengan topik dan pokok masalah. Penelitian ini bercorak pure library research (penelitian kepustakaan murni). Dengan mempelajari kitab-kitab tafsir seperti tafsir Al-Misbah, Tafsir Ibnu Qoyim, Al-Maraghi dan Tafsir Adwa'ul Bayan dan Tafsir Al- Qurthubi.

\section{B. KOMPETENSI PENDIDIK AGAMA}

Pendidikan merupakan sesuatu yang penting dan utama dalam konteks pembangunan bangsa dan negara. Hal ini dapat terlihat dari tujuan nasional bangsa Indonesia yang salah satunya yaitu mencerdaskan kehidupan bangsa yang menempati posisi yang strategis dalam pembukaan UUD 1945. Dalam situasi pendidikan, khususnya pendidikan formal di sekolah, guru merupakan komponen yang paling penting dalam meningkatkan mutu pendidikan. Ini disebabkan guru berada di barisan terdepan dalam pelaksanaan pendidikan. Gurulah yang langsung berhadapan dengan peserta didik untuk mentransfer ilmu pengetahuan dan teknologi sekaligus mendidik dengan nilai-nilai positif melalui dengan bimbingan dan keteladanan. ${ }^{5}$

Guru adalah pendidik yang berbakti membimbing peserta didik untuk membentuk manusia Indonesia seutuhnya yang berjiwa pancasila. Ngainun Naim dalam bukunya "Menjadi Guru Inspiratif" mendefinisikan bahwa guru adalah sosok yang rela mencurahkan sebagian besar waktunya untuk mengajar dan mendidik siswa, sementara penghargaan lain dari sisi material, misalnya sangat jauh dari harapan. Sedang menurut Oemar Hamalik mendefinisikan guru adalah suatu jabatan profesional yang harus memenuhi kriteria profesional, yang meliputi syarat-syarat fisik, mental/

5 Kunandar, Guru Profesional Implementasi Kurikulum Tingkat Satuan Pendidikan (KTSP) dan Sukses dalam Sertifikasi Guru, (Jakarta; Rajawali Pers, 2010), Ed. Rev, Cet. 6, hal. V. 
kepribadian, keilmuan/pengetahuan dan keterampilan. ${ }^{6}$

Dengan beberapa definisi mengenai guru seperti telah disebutkan di atas, guru atau pendidik merupakan sosok yang seharusnya mempunyai banyak ilmu, mau mengenalkan sungguhsungguh ilmunya tersebut dalam proses pembelajaran dalam makna yang luas, toleran, dan berusaha menjadikan siswanya memiliki kehidupan yang lebih baik. Dengan kata lain, guru merupakan komponen yang paling berpengaruh terhadap terciptanya proses dan hasil pendidikan yang berkualitas dan untuk mewujudkannya guru harus memiliki minimal dasar-dasar kompetensi sebagai wewenang dan kemampuan dalam menjalakan tugas. Dengan demikian, upaya perbaikan apapun yang dilakukan untuk meningkatkan pendidikan tidak akan memberikan sumbangan yang signifikan tanpa didukung oleh guru yang profesional dan berkompeten. Oleh karena itu, diperlukanlah sosok guru yang mempunyai kualifikasi, kompetensi dan dedikasi yang tinggi dalam menjalankan tugas profesionalnya.

Satu kunci pokok tugas dan kedudukan guru sebagai tenaga profesional dijelaskan dalam pasal 4 Undang-undang Guru dan Dosen bahwa kedudukan guru sebagai tenaga profesional berfungsi untuk meningkatkan martabat dan peran guru sebagai agen pembelajaran berfungsi untuk meningkatkan mutu pendidikan nasional. ${ }^{7}$ Hakikat keprofesionalan jabatan guru tidak akan terwujud hanya dengan mengeluarkan pernyataan bahwa guru adalah jabatan/pekerjaan professional, meskipun pernyataan ini dikeluarkan dalam bentuk peraturan resmi. Oleh karena itu, guru harus mempunyai kepribadian yang baik, karena kepribadian adalah unsur yang menentukan keakraban hubungan guru dan anak didik, serta guru bukan saja dituntut untuk lebih aktif mencari informasi yang dibutuhkan, akan tetapi ia juga harus mampu menyeleksi berbagai informasi, sehingga dapat menunjukan kepada siswa informasi yang dianggap perlu dan penting untuk kehidupan mereka.

6 Oemar Hamalik, Pendidikan Guru Berdasarkan Pendekatan Kompetensi, (Jakarta: Bumi Aksara, 2004), hal. 59.

7 Undang-Undang Republik Indonesia Tentang Guru dan Dosen, (Yogyakarta: Pustaka Pelajar, 2006), hal. 8. 
Sebagai agen pembelajaran guru memiliki peran sentral dan cukup strategis. Sebagaiama dijelaskan oleh Pullias dan Young yang dikutip oleh Mulyasa bahwa Peran guru sedikitnya ada 19, yakni guru sebagai pendidik, pengajar, pembimbing, pelatih, penasehat, pembaharu (innovator), model dan teladan, pribadi, peneliti, pendorong, kreativitas, pembangkit pandangan, pekerja rutin, pemindah kemah, pembawa cerita, aktor, emansipator, evaluator, pengawet, dan sebagai kulminator. ${ }^{8}$

Oleh karena itu, agar proses pembelajaran bisa efektif dan efesien harus di dukung dengan faktor pengetahuan guru. Guru tanpa mempunyai pengetahuan dan skill yang memadai, maka bisa dipastikan akan mengalami kesulitan mentransferkan ilmu pengetahuan dan juga bisa menyesatkan peserta didik. Sehingga tujuan pendidikan yang telah direncanakan akan sulit untuk dicapai.

Dalam lembaga persekolahan, tugas utama guru adalah mendidik dan mengajar. Agar tugas utama tersebut dapat dilaksanakan dengan baik, ia perlu memiliki kualifikasi tertentu, yaitu profesionalisme.

Guru yang profesional pada intinya adalah orang yang memiliki keahlian dan kemampuan khusus dalam bidang keguruan sehingga ia mampu melakukan tugas dan fungsinya sebagai guru dengan kemampuan maksimal. Kompetensi berasal dari kata competency, yang berarti kemampuan atau kecakapan. Menurut kamus bahasa Indonesia sebagaimana yang dikutip oleh Mulyasa, bahwa "kompetensi dapat diartikan kekuasaan (kewenangan) untuk menentukan atau memutuskan suatu hal". ${ }^{9}$

Istilah kompetensi guru mempunyai banyak makna, sebagaimana menurut pakar pendidikan dapat kita lihat sebagai berikut; Charles mengatakan, sebagaimana yang dikutip oleh Mulyasa bahwa "kompetensi merupakan perilaku yang rasional untuk mencapai tujuan yang dipersyaratkan sesuai dengan kondisi

8 E. Mulyasa, Menjadi Guru Profesional Menciptakan Pembelajaran Kreatif dan Menyenangkan (Bandung; Rosdakarya, 2011), Cet. 10, Hal 13

9 E. Mulyasa, Standart Kompetensi dan Stratifikasi Guru, (Bandung: Remaja Rosdakarya, 2007), hal. 3. 
yang diharapkan". ${ }^{10}$ Undang-Undang No. 14 tahun 2005 tentang Guru dan Dosen dijelaskan bahwa "kompetensi adalah seperangkat pengetahuan, ketrampilan, dan perilaku yang harus dimiliki, dihayati, dan dikuasai oleh guru dan dosen dalam melaksanakan tugas keprofesionalan". ${ }^{11}$ Menurut Usman sebagaimana yang dikutip Kunandar, kompetensi adalah "suatu hal yang menggambarkan kualifikasi atau kemampuan seseorang, baik yang kualitatif maupun yang kuantitatif". ${ }^{12}$

Dari beberapa pengertian di atas dapat disarikan bahwa pengertian kompetensi guru adalah seperangkat penguasaan kemampuan yang harus ada dalam diri guru agar dapat mewujudkan kinerjanya secara tepat dan efektif. Dari beberapa uraian tersebut tampak bahwa kompetensi mengacu kepada kemampuan melaksanakan sesuatu yang diperoleh melalui pendidikan.

Namun, jika pengertian kompetensi guru tersebut dikaitkan dengan pendidikan agama Islam yakni pendidikan yang sangat penting bagi kehidupan manusia, terutama dalam mencapai ketentraman batin dan kesehatan mental pada umumnya. Agama Islam merupakan bimbingan hidup yang paling baik, pencegah perbuatan salah dan munkar yang paling ampuh, pengendali moral yang tiada taranya. Maka kompetensi guru agama Islam adalah kewenangan untuk menentukan pendidikan agama Islam yang akan diajarkan pada jenjang tertentu di sekolah tempat guru itu mengajar. ${ }^{13}$

Guru agama berbeda dengan guru-guru bidang studi lainnya. Guru pendidikan Islam adalah anggota masyarakat yang beragama Islam yang mengabdikan dan diangkat untuk menunjang penyelenggaraan pendidikan Islam. Guru agama di samping melaksanakan tugas pengajaran, yaitu memberitahukan pengetahuan keagamaan, ia juga melaksanakan tugas pengajaran

10 Ibid., hal. 25.

11 Undang-Undang Republik Indonesia Tentang Guru dan Dosen, (Yogyakarta: Pustaka Pelajar, 2006), hal. 5.

12 Kunandar, Guru Profesional: Implementasi Kuriklum Tingkat Satuan Pendidikan (KTSP) dan Sukes dalam Sertifikasi Guru, (Jakarta: Raja Grafindo Persada, 2009), h. 51. hal.9

13 Zakiyah Daradjat, Pendidikan Islam dalam Keluarga dan Sekolah, (Jakarta: Ruhama,1995), 
dan pembinaan bagi peserta didik, ia membantu pembentukan kepribadian, pembinaan akhlak serta menumbuh kembangkan keimanan dan ketaqwaan para peserta didik. Dalam memilih bahan yang akan diajarkan, guru harus berorientasi kepada anak yang akan menerima pelajaran itu. Bahan itu harus disesuaikan dengan fase perkembangan penghayatan keagamaan anak. Anak sekolah rendah (SD) jangan dituntut untuk menghafalkan bacaan-bacaan yang sukar yang bukan merupakan pokok materi yang menjadikan perbuatan ibadah sah. Jangkauan bagi anak itu jangan terlalu jauh dan dalam, sehingga menyulitkan dan membosankan mereka. Setiap guru harus mengerti dan sadar bahwa pengajaran ibadah itu adalah pengajaran kegiatan beramal/bekerja dalam rangka beribadah, yang diajar harus dapat dengan mudah dan senang mengerjakannya. ${ }^{14}$

Secara umum tujuan pendidikan Islam terbagi kepada; tujuan umum, tujuan sementara, tujuan akhir, dan tujuan operasional. Tujuan umum adalah tujuan yang akan dicapai dengan semua kegiatan pendidikan baik dengan pengajaran atau dengan cara lain. Tujuan sementara adalah tujuan yang akan dicapai setelah anak didik diberi sejumlah pengalaman tertentu yang direncanakan dalam sebuah kurikulum. Tujuan akhir adalah tujuan yang dikehendaki agar peserta didik menjadi manusia-manusia sempurna (Insan kamil) setelah ia menghabisi sisa umurnya. Sementara tujuan operasional adalah tujuan praktis yang akan dicapai dengan sejumlah kegiatan pendidikan Islam dalam perspektif para ulama muslim. ${ }^{15}$

Kemampuan guru khususnya guru agama tidak hanya memiliki keunggulan pribadi yang dijiwai oleh keutamaan hidup dan nilainilai luhur yang dihayati serta diamalkan. Namun seorang guru agama hendaknya memiliki kemampuan paedagogis atau hal-hal mengenai tugas-tugas kependidikan seorang guru agama tersebut.

14 Ibid. hal.76

15 Armai Arief, Ilmu dan Metodologi Pendidikan Islam, (Jakarta: Ciputat Pers, 2002), hal.18-19. 


\section{MACAM-MACAM KOMPETENSI PENDIDIK AGAMA}

Secara umum, guru harus memenuhi dua kategori yaitu memiliki capability dan loyality, yakni guru itu harus memiliki kemampuan dalam bidang ilmu yang diajarkannya, memiliki kemampuan teoritik tentang mengajar yang baik dan mulai perencanaan, implementasi sampai evaluasi dan memiliki loyalitas keguruan, yakni terhadap tugas-tugas yang tidak semata di dalam kelas, tapi sebelum dan sesudah kelas. ${ }^{16}$

Kedua kategori, capability dan loyality tersebut, terkandung dalam macam-macam kompetensi guru. Sebagaimana dijelaskan dalam Pasal 10 Undang-Undang Republik Indonesia nomor 14 tahun 2005 kompetensi guru meliputi kompetensi pedagogik, kompetensi kepribadian, kompetensi sosial, dan kompetensi profesional.

\section{Kompetensi pedagogik}

Yang dimaksud dengan kompetensi pedagogik adalah kemampuan mengelola pembelajaran peserta didik. ${ }^{17}$ Kompetensi ini meliputi pemahaman terhadap peserta didik, perancangan dan pelaksanaan pembelajaran, evaluasi hasil belajar, dan pengembangan peserta didik untuk mengaktualisasikan berbagai potensi yang dimilikinya. Kompetensi pedagogik merupakan kemampuan guru dalam pengelolaan pembelajaran peserta didik yang sekurangkurangnya meliputi hal-hal sebagai berikut :
a) Pemahaman wawasan / landasan kependidikan.
b) Pemahaman terhadap peserta didik.
c) Pengembangan kurikulum / silabus.
d) Perancangan pembelajaran.
e) Pelaksanaan pembelajaran yang mendidik dan dialogis.
f) Pemanfaatan tekhnologi pembelajaran.

16 Dede Rosyada, Paradigma Pendidikan Demokratis: Sebuah Model Pelibatan Masyarakat dalam Penyelenggaraan Pendidikan, (Jakarta: Prenada Media, 2004), hal. 112-113.

17 Asrorun Ni'am, Membangun Profesionalitas Guru, (Jakarta : eLSAS, 2006), hal. 199. 
g) Evaliasi Hasil Belajar (EHB).

h) Pengembangan peserta didik untuk mengaktualisasikan berbagai potensi yang dimilikinya. ${ }^{18}$

Menurut Permendiknas Nomor 16 Tahun 2007 kompetensi pedagogik guru mata pelajaran terdiri atas 37 buah kompetensi yang dirangkum dalam 10 kompetensi inti seperti disajikan berikut ini.

1) Menguasai karakteristik peserta didik dari aspek fisik, moral, spiritual, sosial, kultural, emosional, dan intelektual.

2) Menguasai teori belajar dan prinsip-prinsip pembelajaran yang mendidik.

3) Mengembangkan kurikulum yang terkait dengan mata pelajaran yang diampu.

4) Menyelenggarakan pembelajaran yang mendidik.

5) Memanfaatkan teknologi informasi dan komunikasi untuk kepentingan pembelajaran.

6) Memfasilitasi pengembangan potensi peserta didik untuk mengaktualisasikan berbagai potensi yang dimiliki.

7) Berkomunikasi secara efektif, empatik, dan santun dengan peserta didik.

8) Menyelenggarakan penilaian dan evaluasi proses dan hasil belajar.

9) Memanfaatkan hasil penilaian dan evaluasi untuk kepentingan pembelajaran.

10) Melakukan tindakan reflektif untuk peningkatan kualitas pembelajaran.

\section{Kompetensi kepribadian}

Kompetensi Kepribadian adalah kemampuan kepribadian yang mantap, berakhlak mulia, arif dan berwibawa serta menjadi teladan peserta didik. ${ }^{19}$ Dalam standar nasional

18 E. Mulyasa, Standar Kompetensi..., Op. Cit., hal. 75.

19 Asrorun Ni'am, Membangun..., Op. Cit., hal. 199. 
pendidikan, dikemukakan bahwa yang dimaksud dengan kompetensi kepribadian adalah kemampuan kepribadian yang mantap, stabil, dewasa, arif, dan berwibawa, menjadi teladan bagi peserta didik dan berakhlak mulia. Kompetensi kepribadian sangat besar pengaruhnya terhadap pertumbuhan dan perkembangan pribadi para peserta didik, yang meliputi:
a) Mantap;
b) Stabil;
c) Dewasa;
d) Arif dan bijaksana;
e) Berwibawa;
f) Berakhlak mulia;
g) Menjadi teladan bagi peserta didik dan masyarakat;
h) Mengevaluasi kinerja sendiri; dan
i) Mengembangkan diri secara berkelanjutan. ${ }^{20}$

Kompetensi kepribadian ini memiliki peran dan fungsi yang sangat penting dalam membentuk kepribadian anak, guna menyiapkan dan mengembangkan sumber daya manusia (SDM) serta mensejahterakan masyarakat, kemajuan negara, dan bangsa pada umumnya.

\section{Kompetensi sosial}

Kompetensi sosial adalah kemampuan guru sebagai bagian dari masyarakat untuk berkomunikasi dan bergaul secara efektif dengan peserta didik, sesama pendidik, tenaga kependidikan, orang tua / wali peserta didik dan masyarakat sekitar. Kompetensi sosial merupakan kemampuan guru sebagai bagian dari masyarakat yang sekurang-kurangnya memiliki kompetensi untuk:

a) Berkomunikasi secara lisan, tulisan dan isyarat.

b) Menggunakan teknologi komunikasi dan informasi secara fungsional. 
c) Bergaul secara efektif dengan peserta didik, sesama pendidik, tenaga kependidikan, orang tua / wali peserta didik; dan

d) Bergaul secara santun dengan masyarakat sekitar. ${ }^{21}$

\section{Kompetensi profesional}

Yang dimaksud kompetensi profesional adalah kemampuan penguasaan materi pelajaran secara luas dan mendalam. Kompetensi profesional merupakan kemampuan penguasaan materi, pembelajaran secara luas dan mendalam yang memungkinkan membimbing peserta didik memenuhi standar kompetensi yang ditetapkan dalam standar nasional pendidikan. Adapun ruang lingkup kompetensi profesional sebagai berikut :

a) Mengerti dan dapat menerapkan landasan kependidikan baik filosofi, psikologis, sosiologis, dan sebagainya.

b) Mengerti dan dapat menerapkan teori belajar sesuai taraf perkembangan peserta didik.

c) Mampu menangani dan mengembangkan bidang studi yang menjadi tanggung jawabnya.

d) Mengerti dan dapat menerapkan metode pembelajaran yang bervariasi.

e) Mampu mengembangkan dan menggunakan berbagai alat, media dan sumber belajar yang relevan.

f) Mampu mengorganisasikan dan melaksanakan program pembelajaran.

g) Mampu melaksanakan evaluasi hasil belajar peserta didik.

h) Mampu menumbuhkan kepribadian peserta didik. ${ }^{22}$

21 E. Mulyasa, Standar Kompetensi..., Op. Cit., hal. 173.

22 Ibid., hal. 135-136. 


\section{PENAFSIRAN SURAT AL-ALAQDALAM TAFSIR AL-MISBAH}

Teks Qur'an Surat Al-Alaq ayat 1-5

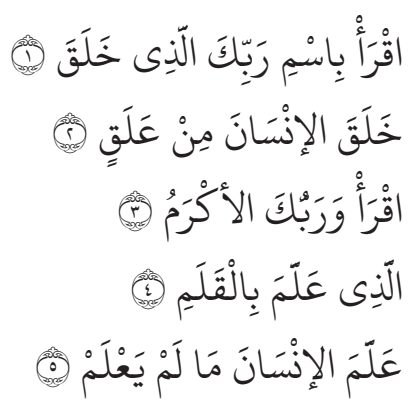

Terjemahan Qur'an Surat Al-Alaq ayat 1-5

Bacalah dengan nama Tuhanmu yang mencipta (1)

Yang telah menciptakan manusia dari 'alaq (2)

Bacalah dan Tuhanmu Maha Pemurah (3)

Yang megajar dengan pena, (4)

Mengajar manusia apa yang belum diketahui(nya) (5)

Surah ini disepakati turun di Mekah sebelum Nabi berhijrah, bahkan hampir semua ulama sepakat bahwa wahyu al-Qur'an pertama yang diterima Nabi Muhammad saw. adalah lima ayat pertama surah ini. Thabathaba'i menulis, bahwa dari konteks uraian ayat-ayatnya, tidak mustahil bahwa keseluruhan ayat-ayat surah ini turun sekaligus. Thahir Ibn 'Asyur menyatakan bahwa lima ayatnya yang pertama turun pada tanggal tujuh belas Ramadhan. Pendapat ini dianut oleh banyak ulama.

Tema utamanya adalah pengajaran kepada Nabi Muhammad saw. serta penjelasan tentang Allah dalam sifat dan perbuatanNya, dan bahwa Dia adalah sumber ilmu pengetahuan. Menurut al-Biqa'i, tujuan utamanya adalah perintah kepada manusia untuk menyembah Allah swt. Sang Pencipta Yang Maha Kuasa, sebagai tanda syukur kepada-Nya. ${ }^{23}$

23 M. Quraish Shihab, Tafsir Al-Misbah: Pesan, kesan dan keserasian Al-Qur'an. Juz' Amma. Volume 15. (Jakarta: Lentera Hati, 2002) hal. 391. 


\section{Ayat 1}

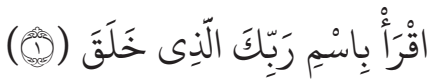

Bacalah dengan nama Tuhanmu yang mencipta

Di sini beliau diperintahkan untuk membaca guna lebih memantapkan lagi hati beliau. Ayat di atas bagaikan menyatakan: Bacalah wahyu-wahyu Ilahi yang sebentar lagi akan banyak engkau terima, dan baca juga alam dan masyarakatmu. Bacalah agar engkau membekali dirimu dengan kekuatan pengetahuan. Bacalah semua itu tetapi dengan syarat hal tersebut engkau lakukan dengar atau demi nama Tuhan Yang selalu memelihara dan membimbingnu dan Yang mencipta semua makhluk kapan dan di manapun.

Kata iqra' terambil dari kata kerja qara'a yang pada mulanya berarti menghimpun. Apabila Anda merangkai huruf atau kata kemudian Anda mengucapkan rangkaian tersebut maka Anda telah menghimpunnya yakni membacanya. Dengan demikian, realisasi perintah tersebut tidak mengharuskan adanya suatu teks tertulis sebagai objek bacaan, tidak pula harus diucapkan sehingga terdengar oleh orang lain. Karenanya, dalam kamuskamus ditemukan aneka ragam arti dari kata tersebut. Antara Iain: menyampaikan, menelaah, membaca, mendalami, meneliti, mengetahui ciri-ciri sesuatu dan sebagainya, yang ke semuanya bermuara pada arti menghimpun.

Kaidah kebahasaan menyatakan, "Apabila suatu kata kerja yang membutuhkan objek tetapi tidak disebutkan objeknya, maka objek yang dimaksud bersifat umum, mencakup segala sesuatu yang dapat dijangkau oleh kata tersebut." Dari sini dapat ditarik kesimpulan bahwa karena kata iqra' digunakan dalam arti membaca, menelaah, menyampaikan dan sebagainya, dan karena objeknya bersifat umum, maka objek kata tersebut mencakup segala yang dapat terjangkau, baik ia merupakan bacaan suci yang bersumber dari Tuhan maupun bukan, baik ia menyangkut ayat-ayat yang tertulis maupun yang tidak tertulis. Alhasil perintah iqra' mencakup telaah terhadap alam 
raya, masyarakat dan diri sendiri, serta bacaan tertulis, baik suci maupun tidak.

Huruf $b a^{\prime}$ pada kata bismi ada juga yang memahaminya sebagai berfungsi Penyertaan atau mulabasah sehingga dengan demikian ayat tersebut berarti "bacalah disertai dengan nama Tuhanmu."

Mengaitkan pekerjaan membaca dengan nama Allah mengantarkan pelakunya untuk tidak melakukannya kecuali karena Allah dan hal ini akan menghasilkan keabadian karena hanya Allah Yang Kekal Abadi dan hanya aktivitas yang dilakukan secara ikhlas yang akan diterima-Nya. Tanpa keikhlasan, semua aktivitas akan berakhir dengan kegagalan dan kepunahan

Syeikh 'Abdul Halim Mahmud (mantan Pemimpin Tertinggi al-Azhar Mesir) yang menulis dalam bukunya, al-Qur'an Fi Syahr al-Qur'an bahwa: 'Dengan kalimat iqra' bismi Rabbik, al-Qur'an tidak sekadar memerintahkan untuk membaca, tapi 'membaca' adalah lambang dari segala apa yang dilakukan oleh manusia, baik yang sifatnya aktif maupun pasif. Kalimat tersebut dalam pengertian dan semangatnya ingin menyatakan 'Bacalah demi Tuhanmu, bergeraklah demi Tuhanmu, bekerjalah demi Tuhanmu.' Demiklan juga apabila Anda berhenti bergerak atau berhenti melakukan sesuatu aktivitas, maka hendaklah hal tersebut juga didasarkan pada bismi Rabbik sehingga pada akhirnya ayat tersebut berarti 'Jadikanlah seluruh kehidupanmu, wujudmu, dalam cara dan tujuannya, kesemuanya demi karena Allah.”

Kata rabb seakar dengan kata tarbiyah/pendidikan. Kata ini memiliki arti yang berbeda-beda namun pada akhirnya arti-arti itu mengacu kepada pengembangan, peningkatan, ketinggian, kelebihan serta perbaikan. Kata rabb maupun tarbiyah berasal dari kata raba-yarbu yang dari segi pengertian kebahasaan adalah kalebihan. Dataran tinggi dinamai rabwah, sejenis roti yang dicampur dengan air sehingga membengkak dan membesar disebut ar-rabw. 
Kata Rabb apabila berdiri sendiri maka yang dirnaksud adalah "Tuhan” yang tentunya antara lain karena Dialah yang melakukan tarbiyah (pendidikan) yang pada hakikatnya adalah pengembangan, peningkatan serta perbaikan makhluk ciptaanNya.

Agaknya penggunaan kata Rabb dalam ayat ini dan ayatayat semacamnya dimaksudkan untuk menjadi dasar perintah mengikhlaskan diri kepada-Nya, sambil menunjuk kewajaranNya untuk disembah dan ditaati.

Dalam wahyu-wahyu pertama yang diterima Nabi Muhammad saw. tidak ditemukan kata Allah, tetapi kata yang digunakan menunjuk Tuhan adalah Rabbuka/Tuhannu wahai Nabi Muhammad - yakni bukan Tuhan yang dipercaya kaum musyrikin. Perhatikan lima ayat pertama surah ini, denukian juga wahyu berikutnya, surah al-Muddats-tsir, al-Qalam, awal surah al-Muzzammil dan surah Tabbat. Surah-surah sesudahnya sampai dengan surah Sabbihisma kesemuanya tanpa menggunakan kata Allah, kecuali bila ayat surah itu turun terpisah dengan ayat-ayat surah lainnya. Rujuklah ke buku penulis, Tafsir Atas Surah-Surah Pendek Berdasar Turunnya Wahyu surah Sabbihisma. Tidak digunakannya kata Alläh karena kaum musyrikin percaya juga kepada Allah, tetapi keyakinan mereka tentang Allah jauh berbeda dengan keyakinan yang dihayati dan diajarkan oleh Nabi Muhammad saw. Mereka misalnya beranggapan bahwa ada hubungan tertentu antara Allah dan Jin (QS. ash-Shaffat [37]: 158) dan bahwa Allah memiliki anak-anak wanita (QS. al-Isra' [17]: 40) dan bahwa mereka tidak dapat berkomunikasi secara langsung kepada-Nya sehingga para malaikat dan berhala-berhala perlu disembah sebagai perantara antara manusia dengan Allah (QS. az-Zumar [39]: 3). Kepercayaan seperti yang dikemukakan ini jelas berbeda dengan ajaran al-Qur'an atau yang diyakini Oleh Nabi Muhammad saw. Hingga jika seandainya dinyatakan Iqra' bismillah atau "Tercayalah kepada Allah," maka kaum musyrikin akan berkata "Kami telah melakukannya." 
Kata khalaqa dari segi pengertian kebahasaan memiliki sekian banyak arti, antara lain; menciptakan (dari tiada), menciptakan (tanpa satu contoh terlebih dahulu), mengukur, memperhalus, mengatur, membuat dan sebagainya. Kata ini biasanya memberikan tekanan tentang kehebatan dan kebesaran Allah dalam ciptaan-Nya. Berbeda dengan kata ja'ala yang mengandung penekanan terhadap manfaat yang harus atau dapat dlperoleh dari sesuatu yang dijadikan itu. Objek khalaqa pada ayat ini tidak disebutkan sehingga objeknya pun sebagaimana iqra' bersifat umum, dan dengan demikian Allah adalah Pencipta semua makhluk. ${ }^{24}$

\section{Ayat 2}

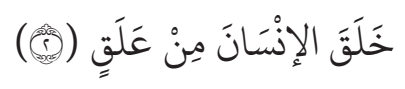

Yang telah menciptakan manusia dari 'alaq.

Ayat ini dan ayat-ayat berikut memperkenalkan Tuhan yang disembah oleh Nabi Muhammad saw. dan yang diperintahkan oleh ayat yang lalu untuk membaca dengan nama-Nya serta demi untuk-Nya. Dia adalah Tuhan yang telah menciptakan manusia yakni semua manusia kecuali Adam dan Hawwa' dari 'alaq segumpal darah atau sesuatu yang bergantung di dinding rahim.

Dalam memperkenalkan perbuatan-perbuatan-Nya, penciptaan merupakan hal pertama yang dipertegas, karena ia merupakan persyaratan bagi terlaksananya perbuatanperbuatan yang lain. Rincian mengenai pengenalan tersebut ditemukan dalam ayat-ayat yang turun kemudian, khususnya pada periode Mekah. Perlu digarisbawahi bahwa pengenalan tersebut tidak hanya tertuju kepada akal manusia tetapi juga kepada kesadaran batin dan intuisinya bahkan seluruh totalitas manusia, karena pengenalan akal semata-mata tidak berarti banyak. Sementara pengenalan hati diharapkan dapat membimbing akal dan pikiran sehingga anggota tubuh dapat

24 M. Quraish Shihab, Tafsir Al-Misbah: Pesan, kesan dan keserasian Al-Qur'an. Juz' Amma. Volume 15. (Jakarta: Lentera Hati, 2002) hal. 396. 
menghasilkan perbuatan-perbuatan baik serta memelihara sifat-sifat terpuji.

Kata al-insan terambil dari akar kata uns/senang, jinak dan harmonis, atau dari kata nis-y yang berarti lupa. Ada juga yang berpendapat berasal dari kata naus yakni gerak atau dinamika.

Makna-makna di atas paling tidak memberikan gambaran sepintas tentang potensi atau sifat makhluk tersebut yakni bahwa ia memiliki sifat lupa, dan kemampuan bergerak yang melahirkan dinamika. Ia juga adalah makhluk yang selalu atau sewajarnya melahirkan rasa senang, harmonisme dan kebahagiaan kepada pihak-pihak lain.

Kata insan menggambarkan manusia dengan berbagai keragaman sifatnya. Kata ini berbeda dengan kata basyar yang juga diterjemahkan dengan "manusia" tetapi maknanya lebih banyak mengacu kepada manusia dengan segi fisik serta nalurinya yang tidak berbeda antara seseorang manusia dengan manusia lain.

Manusia adalah makhluk pertama yang disebut Allah dalam al-Qur'an melalui wahyu pertama. Bukan saja karena ia diciptakan dalam bentuk yang sebaik-baiknya, atau karena segala sesuatu dalam alam raya ini diciptakan dan ditundukkan Allah demi kepentingannya, tetapi juga karena Kitab Suci al-Qư’ån ditujukan kepada manusia guna menjadi pelita kehidupannya. Salah satu cara yang ditempuh oleh al-Qur'an untuk mengantar manusia menghayati petunjuk-petunjuk Allah adalah memperkenalkan jati dirinya antara lain dengan menguraikan proses kejadiannya. Ayat kedua surah Iqra' menguraikan secara sangat singkat hal tersebut.

Kata 'alaq dalam kamus-kamus bahasa Arab digunakan dalam arti segumpal darah, juga dalam arti cacing yang terdapat di dalam air bila diminum oleh binatang maka ia tersangkut di kerongkongannya. Banyak ulama masa lampau memahami ayat di atas dalam pengertian pertama. Tetapi ada juga yang memahaminya dalam arti sesuatu yang tergantung di dinding 
rahim. Ini karena para pakar embriologi menyatakan bahwa setelah terjadinya pertemuan antara sperma dan indung telur ia berproses dan membelah menjadi dua, kemudian empat, kemudian delapan demikian seterusnya sambil bergerak menuju ke kantong kehamilan dan melekat berdempet serta masuk ke dinding rahim.

Bisa juga kata 'alaq dipahami sebagai berbicara tentang sifat manusia sebagai makhluk sosial yang tidak dapat hidup sendiri tetapi selalu bergantung kepada selainnya. Ini serupa dengan firman Allah khuliqa al-insinu min 'ajal/ manusia diciptakan (bersifat tergesa-gesa) (QS. al-Anbiya' [21]: 37). ${ }^{25}$

\section{Ayat 3}

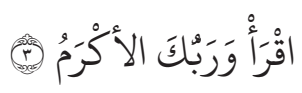

Bacalah dan Tuhanmu Maha Pemurah.

Setelah memerintahkan membaca dengan meningkatkan motivasinya yakni dengan nama Allah, kini ayat di atas memerintahkan membaca dengan menyampaikan janji Allah atas manfaat membaca itu. Allah berfirman: Bacalah berulangulang dan Tuhan Pemelihara dan pendidik-mu Maha Pemurah sehingga akan melimpahkan aneka karunia.

Ayat tiga di atas mengulangi perintah membaca. Ularna pendapat tentang tujuan pengulangan itu. Ada yang menyatakan perintah pertama ditujukan kepada pribadi Nabi Muhammad saw., sedang yang kedua kepada umatnya, atau yang pertama untuk membaca dalam shalat, sedang yang kedua di luar shalat. Pendapat ketiga menyatakan yang pertama perintah belajar, sedang yang kedua adalah perintah mengajar orang lain. Ada lagi yang menyatakan bahwa perintah kedua berfungsi mengukuhkan guna menanamkan rasa "percaya diri" kepada Nabi Muhammad saw., tentang kemampuan beliau membaca - karena tadinya beliau tidak pernah membaca.

Hemat penulis, perintah membaca yang kedua ini 
dimaksudkan agar beliau lebih banyak membaca, menelaah, memperhatikan alam raya serta membaca kitab yang tertulis dan tidak tertulis dalam rangka mempersiapkan diri terjun ke masyarakat.

Kata al-akram biasa diterjemahkan dengan yang Mahal Paling Pemurah atau Semulia-mulia. Kata ini terambil dari kata karama yang antara lain berarti: memberikan dengan mudah dan tanpa pamrih, bernilai tinggi, terhormat, mulia, setia dan sifat kebangsawanan.

Dalam al-Qur'an ditemukan kata karim terulang sebanyak 27 kali. Tidak kurang dari tiga belas subjek yang disifati dengan kata tersebut, yang tentu saja berbeda-beda maknanya dan karena itu pada akhirntya dapat disimpulkan bahwa kata ini digunakan untuk menggambarkan sifat terpuji yang sesuai dengan objek yang disifatinya. Ucapan yang karim adalah ucapan baik, indah terdengar, benar susunan dan kandungannya, mudah dipahami serta menggambarkan segala sesuatu yang ingin disampaikan oleh pembicara. Sedang rezeki yang karim adalah yang memuaskan, bermanfaat serta halal.

Allah menyandang sifat Karim. Menurut Imam Ghazali sifat ini menunjuk kepada-Nya yang mengandung makna antara lain bahwa: "Dia yang bila berjanji, menepati janjiNya; bila memberi, melampaui batas harapan pengharap-Nya. Tidak peduli berapa dan kepada siapa Dia memberi. Dia yang tidak rela bila ada kebutuhan yang dimohonkan kepada selainNya. Dia yang bila (kecil hati), menegur tanpa berlebih. Tidak mengabaikan siapa pun yang menuju dan berlindung kepadaNya, dan tidak membutuhkan sarana atau perantara."

Kata al-Karim yang menyifati Allah dalam al-Qư’ån, kesemuanya menunjuk kepada-Nya dengan kata Rabb, bahkan demikian juga kata Akram sebagaimana terbaca di atas.

Penyifatan Rabb dengan Karim menunjukkan bahwa Karam (anugerah kemurahan-Nya dalam berbagai aspek), dikaitkan dengan Rubibiyyah-Nya yakni pendidikan, pemeliharaan dan 
perbaikan makhluk-Nya, sehingga anugerah tersebut dalam kadar dan waktunya selalu berbarengan serta bertujuan perbaikan dan pemeliharaan.

Kata al-akram yang berbentuk superlatif adalah satusatunya ayat di dalam al-Qur'an yang menyifati Tuhan dalam bentuk tersebut. Ini mengandung pengertian bahwa Dia dapat menganugerahkan puncak dari segala yang terpuji bagi setiap hamba-Nya, terutama dalam kaitannya dengan perintah membaca. Dari sini kita tidak wajar memahami perintah membaca yang kedua ini hanya terbatas tujuannya untuk menolak alasan Nabi "saya tidak dapat membaca," tidak pula sekadar untuk menanamkan rasa percaya diri, atau berfungsi pengganti "mengulang-ulangi bacaan," tetapi jauh lebih dalam dan lebih luas, seluas pengertian kata Akram yang berbentuk superlatif dan seluas kata Karam yang menyifati Allah swt, sebagai makhluk kita tidak dapat menjangkau betapa besar Allah swt. Karena keterbatasan kita di hadapan-Nya. Namun demikian darinya dapat diungkapkan sebagai berikut:

"Bacalah wahai Nabi Muhammad, Tuhanmu akan menganugerahkan dengan sifat kemgruhan-Nya pengetahuan tentang apa yang tidak engkau ketahui, Bacalah dan ulangi bacaan tersebut walaupun objek sama, niscaya Tuhanmu akan memberikan pandangan serta pengertian baru yang tadinya engkau belum peroleh pada bacaan pertama dalam objek tersebut." "Bacalah dan ulangi bacaan, Tuhanmu akan memberi manfaat kepadamu, manfaat yang banyak tidak, terhingga karena Dia Akram, memiliki segala macam kesempurnaan."

Di sini kita dapat melihat perbedaan antara perintah membaca pada ayat pertama dan perintah membaca pada ayat ketiga, yakni yang Pertama menjelaskan syarat yang harus dipenuhi seseorang ketika membaca (dalam segala pengertian) yaitu membaca demi karena Allah, sedang perintah yang kedua menggambarkan manfaat yang diperoleh dari bacaan bahkan pengulangan bacaan tersebut. 
Dalam ayat ketiga ini Allah menjanjikan bahwa pada saat seseorang membaca denganikhlaskarenaAllah, makaAllah akan menganugerahkan kepadanya ilmu pengetahuan, pemahamanpemahaman, wawasan-wawasan baru walaupun yang dibacanya itu-itu juga. Apa yang dijanjikan ini terbukti secara sangat jelas. Kcgiatan "membaca" ayat al-Qur'an menimbulkan penafsiranpenafsiran baru atau pengembangan dari pendapat-pendapat yang telah ada. Demikian juga, kegiatan "membaca" alam raya ini telah mcnimbulkan penemuan-penemuan baru yang membuka rahasia-rahasia alam, walaupun objek bacaannya itu-itu juga. Ayat al-Qur'an yang dibaca oleh generasi terdahulu dan alam raya yang mereka huni, adalah sama tidak berbeda, namun pemahaman mereka serta penemuan rahasianya terus berkembang. ${ }^{26}$

\section{Ayat 4-5}

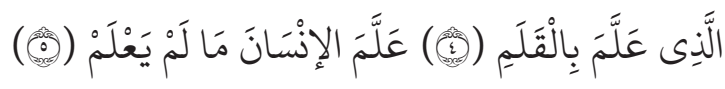

Yang megajar dengan pena, Mengajar manusia apa yang belum diketahui(nya)

Ayat-ayat yang lalu menegaskan kemurahan Allah swt. Ayat di atas melanjutkan dengan memberi contoh sebagian dari kemurahan-Nya itu dengan menyatakan bahwa: Dia Yang Maha Pemurah itu yang mengajarkan manusia dengan pena yakni dengan sarana dan usaha mereka, dan Dia juga yang mengajarkan manusia tanpa alat dan usaha mereka apa yang diketahui-nya.

Kata al-qalam terambil dari kata kerja qalama yang berarti memotong ujung sesuatu. Memotong ujung kuku disebut taqlim. Tombak yang dipotong ujungnya sehingga meruncing dinamai maqalim. Anak panah yang runcing ujungnya dan yang bisa digunakan untuk mengundi pula qalam (baca QS. 'Imran [3]: 44). Alat yang digunakan untuk dinamai pula qalam karena pada mulanya alat tersebut dibuat dari suatu bahan yang dipotong dan diperuncing ujungnya.

26 M. Quraish Shihab, Tafsir Al-Misbah: Pesan, kesan dan keserasian Al-Qur'an. Juz' Amma. Volume 15. (Jakarta: Lentera Hati, 2002) hal. 400. 
Kata qalam di sini dapat berarti hasil penggunaan ayat tersebut, yakni tulisan. Ini karena bahasa, sering kali menggunakan kata yang berarti "alat" atau "penyebab" untuk menunjuk "akibat" atau "hasil" dari penyebab atau penggunaan alat tersebut. Misalnya, jika seseorang berkata, "saya khawatir hujan," maka yang dimaksud dengan kata "hujan" adalah basah atau sakit, hujan adalah penyebab semata.

Makna di atas dikuatkan oleh firman Allah dalam QS. alQalam [68]: 1 yakni firman-Nya: Nun demi Qalam dan apa yang mereka tulis. Apalagi disebutkan dalam sekian banyak riwayat bahwa awal surah al-Qalam turun setelah akhir ayat kelima surah al-'Alaq. Ini berarti dari segi masa turunnya kedua kata qalam tersebut berkaitan erat, bahkan bersambung walaupun urutan penulisannya dalam mushhaf tidak demikian.

Pada kedua ayat di atas terdapat apa yang dinamai ihtibak yang maksudnya adalah tidak disebutkan sesuatu keterangan, yang sewajarnya ada pada dua susunan kalimat yang bergandengan, karena keterangan yang dimaksud telah disebut pada kalimat yang lain. Pada ayat 4 kata manusia tidak disebut karena telah disebut pada ayat 5 , dan pada ayat 5 kalimat tanpa Pena tidak disebut karena pada ayat 4 telah diisyaratkan makna itu dengan disebutnya pena. Dengan demikian kedua ayat di atas dapat berarti "Dia (Allah) mengajarkan dengan Pena (tulisan) (hal-hal yang telah diketahui manusia sebelumnya) dan Dia mengajarkan manusia (tanpa pena) apa yang belum diketahui sebelumnya." Kalimat "yang telah diketahui sebelumnya disisipkan karena isyarat pada susunan kedua yaitu "yang belum atau tidak diketahui sebelumnya." sedang kalimat "tanpa pena" ditambahkan karena adanya kata "dengan pena" dalam susunan pertama, Yang dimaksud dengan ungkapan "telah diketahui sebelumnya" adalah khazanah pengetahuan dalam bentuk tuhsan.

Dari uraian di atas kita dapat menyatakan bahwa kedua ayat di atas menjelaskan dua cara yang ditempuh Allah swt. dalam mengajar manusia Pertama melalui pena (tulisan) yang 
harus dibaca oleh manusia, dan yang kedua melalui pengajaran secara langsung tanpa alat. Cara yang kedua ini dikenal dengan istilah Ilmu Laduniy.

Pada awal surah ini, Allah telah memperkenalkan diri sebagai Yang Maha Kuasa, Maha Mengetahui dan Maha Pemurah. Pengetahuan-Nya meliputi segala sesuatu. Sedangkan Karam (kemurahan)-Nya tidak terbatas sehingga Dia kuasa dan berkenan untuk mengajar manusia dengan atau tanpa pena.

Wahyu-wahyu Ilahi yang diterima oleh manusia-manusia agung yang suci jiwanya adalah tingkat tertinggi dari bentuk pengajaran-Nya tanpa alat dan tanpa usaha manusia. Nabi Muhammad saw. dijanjikan oleh Allah dalam wahyu-Nya yang pertama untuk termasuk dalam kelompok tersebut. ${ }^{27}$

\section{E. KOMPETENSI PENDIDIK AGAMA YANG TERKANDUNG DALAM Q.S. AL-ALAQ}

\section{Kompetensi yang terdapat pada ayat 1}

Kompetensi pertama dari pendidik adalah kompetensi pedagogik dan kompetensi keagamaan. Kompetensi pedagogik dipahami dari penafsiran atas kata iqra. Makna perintah iqra bukanlah hanya sebatas membaca dalam arti membaca teks, tetapi makna iqra adalah membaca dengan melibatkan pemikiran dan pemahaman. ${ }^{28}$ Kompetensi keagamaan dipahami dari pengaitan kata iqra dengan kata bismi rabbika. Pengaitan ini merupakan syarat sehingga menuntut dari si pembaca bukan sekedar melakukan bacaan dengan ikhlas, tetapi juga antara lain memilih bahan bacaan yang tidak mengantarkannya kepada hal-hal yang bertentangan dengan nama Allah itu. ${ }^{29}$

27 M. Quraish Shihab, Tafsir Al-Misbah: Pesan, kesan dan keserasian Al-Qur'an. Juz' Amma. Volume 15. (Jakarta: Lentera Hati, 2002) hal. 402.

28 Lajnah Pentashihan Mushaf Al-Qur'an, Pendidikan, Pembangunan karakter, dan Pengembangan Sumber Daya Manusia (Jakarta: Aku Bisa, 2012), hal. 404.

29 M. Quraish Shihab, Membumikan AL-Qur'an: Fungsi dan Peran Wahyu dalam Kehidupan Masyarakat, (Mizan: Bandung, 2013), hal. 264. 


\section{Kompetensi yang terdapat pada ayat 2}

Kompetensi yang terdapat dalam penafsiran Qurasih Shihab dalam ayat kedua adalah kompetensi sosial. Kompetensi tersebut dapat dipahami dari penafsiran Quraish Shihab, pada kata "insana" dan kata "alaq." Memahami proses kejadian manusia, pendidik dapat memahami sifat manusia sebagai makhluk sosial yang tidak dapat hidup sendiri tetapi selalu bergantung kepada selainnya yang dipahami dari kata alaq, dimana Quraish Shihab lebih memahaminya dalam arti sesuatu yang tergantung di dinding rahim. ${ }^{30}$

Pendidik yang memiliki kompetensi sosial ini pada akhirnya akan mampu berkomunikasi secara efektif, empatik, dan santun dengan sesama pendidik, tenaga kependidikan, orang tua, dan masyarakat. ${ }^{31}$ Pendidik dalam pendidikan Islam dengan demikian, tidak hanya dituntut untuk mendidik saja, tetapi dia juga harus menyadari kedudukan dan tugasnya sebagai anggota masyarakat yang dituntut untuk aktif dalam melakukan perbaikan dan peningkatan kualitas masyarakat.

\section{Kompetensi yang terdapat pada ayat 3}

Kompetensi yang terdapat dalam penafsiran ayat ketiga ini sama dengan yang terdapat dalam ayat pertama, yaitu kompetensi pedagogik dan kompetensi personal. Ayat ketiga ini lebih pada penekanan untuk lebih meningkatkan lagi kegiatan iqra. Penafsiran pada ayat ketiga ini hanya menjelaskan syarat yang harus dipenuhi dalam melakukan setiap tindakan, sedangkan pada ayat ketiga menggambarkan manfaat yang diperoleh dari setiap tindakan. Hal ini dipahami dari penafsiran Quraish Shihab,tentang diulangnya kata iqra pada ayat di atas.

Akhir ayat ini dijelaskan tentang makna al-akram oleh Quraish Shihab, yang menjelaskan manfaat dari kegiatan iqra yaitu Allah akan menganugerahkan puncak dari segala

30 M. Quraish Shihab, Tafsir Al-Misbah: Pesan, kesan dan keserasian Al-Qur'an. Juz' Amma. Volume 15. (Jakarta: Lentera Hati, 2002) hal. 396-397

31 M. Quraish Shihab, Membumikan AL-Qur'an: Fungsi dan Peran Wahyu dalam Kehidupan Masyarakat, (Mizan: Bandung, 2013), hal. 379. 
yang terpuji bagi setiap hamba-Nya. Terutama hamba yang melaksanakan iqra. Allah Yang Maha Pendidik (rabbun) bersifat pemurah, sehingga manusia yang berfungsi sebagai pendidik harus mengadopsi sifat Allah tersebut sesuai dengan tataran kemanusiaannya. ${ }^{32}$

\section{Kompetensi yang terdapat pada ayat 4-5}

Kompetensi yang terdapat dalam penafsiran ayat yang keempat dan kelima adalah kompetensi pedagogik. Pendidik dalam hal ini harus menuangkan apa yang telah dia iqra dalam bentuk tulisan. Hal ini dapat dipahami dari penafsiran Quraish Shihab, ${ }^{33}$ pada kata alqalam. Allah mengajar dengan al-qalam, mengandung isyarat bahwa untuk mengembangkan ilmu tidak lepas dengan aktivitas tulis menulis. Budaya baca disimbolkan dalam perintah iqra, sementara budaya tulis disimbolkan dalam kata al-qalam. ${ }^{34}$

Kompetensi lain yang dapat dipahami dari ayat kelima adalah kompetensi profesional-religius, kompetensi demikian dipahami dari kalimat mengajar manusia apa yang belum diketahui(nya). Dalam rangkaian ayat ini, terkandung nilai-nilai pedagogis yang sangat berharga untuk pendidik praktikkan dalam dunia pendidikan, yaitu nilai keteladanan (qudwah / uswah). Menurut Syahidin, metode keteladanan adalah suatu metode pendidikan dengan cara memberikan contoh yang baik kepada peserta didik, baik dalam ucapan maupun dalam perbuatan. Nilai keteladanan yang dapat dipahami dari ayat ini adalah pendidik meneladani sifat Allah yang mengajarkan manusia apa yang belum diketahuinya. ${ }^{35}$

32 Muhammad Anis, Tafsir Ayat Pendidikan: Wahyu Pertama sebagai Lonceng Kemajuan Peradaban Umat Manusia. Dalam Antologi Kependidikan Islam: Kajian Pemikirran Pendidikan Islam dan Manajemen Pendidikan Islam (Yogyakarta: UIN Sunan Kalijaga, 2010) Hal. 45

33 M. Quraish Shihab, Tafsir Al-Misbah: Pesan, kesan dan keserasian Al-Qur'an. Juz' Amma. Volume 15. (Jakarta: Lentera Hati, 2002) hal. 401.

34 Lajnah Pentashihan Mushaf Al-Qur'an, Pendidikan, Pembangunankarakter, dan Pengembangan Sumber Daya Manusia (Jakarta: Aku Bisa, 2012), hal. 406.

35 Syahidin, Menelusuri Metode Pendidikan dalam Al-Qur'an. (Bandung: Alfabeta, 2009) hal.150. 


\section{F. MANFAAT KOMPETENSI PENDIDIK BAGI KEBERHASILAN PENDIDIKAN DALAM PERSPEKTIF TAFSIR AL-MISBAH}

Kompetensi pendidik agama seperti yang telah telaah dalam Q.S. Al-alaq perspektif tafsir Al-Misbah akan menghasilkan manfaat bagi keberhasilan dalam pendidikan antara lain:

1. Kompentsi padagogik pada ayat pertama, akan membuat pendidik lebih memahami anak didiknya dengan membaca karakter dari setiap anak didiknya, kelebihan dan kekurangan dari anak didiknya. Hal tersebut akan menghasilkan cara yang baik agar setiap anak didiknya mampu menerima ilmu yang diajarkan kepadanya.

2. Kompetensi sosial pada ayat kedua, membuat pendidik lebih aktif dalam berkomunikasi dengan anak didiknya, komunikasi internal maupun external karena tidak semua murid/siswa sulit menerima pelajaran dikarenakan bodoh, terkadang faktor internal dan external dapat mempengaruhinya, seperti masalah dalam keluarga. Hal inilah yang mendorong pendidik untuk berkomunikasi secara efektif empatik dan santun kepada sesama pendidik, orang tua murid dan masyarakat dalam melakukan perbaikan internal dan external untuk anak didiknya sehingga menghasilkan peningkatan kualitas masyarakat yang lebih baik.

3. Kompetensi kepribadian pada ayat ketiga, mengharuskan pendidik mengadopsi sifat-sifat Allah Yang Maha Mulia dan Maha Pemurah. Pendidik yang memiliki kepribadian yang mantap, dewasa, arif dan bijaksana, berwibawa, berakhlak mulia akan menjadi teladan yang baik bagi peserta didiknya dan masyarakan. Hal tersebut akan menghasilkan cetakan peseta didik yang berpendidikan dan berkahlak mulia.

4. Kompetensi profesional pada ayat ke empat dan kelima, mengajarkan pendidik untuk lebih menguasi materi pelajaran secara luas dan mendalam, sehingga mampu memberikan ilmu 
kepada anak didiknya dengan benar secara menyeluruh dan mendalam.

Manfaat yang diperloleh dari 5 ayat di atas akan menghasilkan pendidik yang berkualitas dan berakhlak mulia yang mampu meningkatkan mutu, kualitas dan akhlak dalam dunia pendidikan di Indonesia saat ini. Hal ini lah yang dibutuhkan agar pendidikan kita berhasil mencetak lulusan yang berkualitas sehingga bisa bersain di era global seperti saat ini.

\section{G. KESIMPULN}

Kompetensi pendidik agama dalam Q.S. al-'Alaq perspektif Tafsir al-Misbah karya M. Quraish Shihab terdiri dari kompetensi pedagogik, kompetensi kepribadian, kompetensi sosial, dan kompetensi profesional. Kesimpulan ini mendukung Pasal 10 Undang-Undang Republik Indonesia nomor 14 tahun 2005 tentang kompetensi guru.[] 


\section{DAFTAR PUSTAKA}

Anis, Muhammad. Tafsir Ayat Pendidikan: Wahyu Pertama sebagai Lonceng Kemajuan Peradaban Umat Manusia. Dalam Antologi Kependidikan Islam: Kajian Pemikirran Pendidikan Islam dan Manajemen Pendidikan Islam. Yogyakarta: UIN Sunan Kalijaga. 2010.

Arief, Armai. Ilmu dan Metodologi Pendidikan Islam. Jakarta: Ciputat Pers. 2002

Arifin, M. Ilmu Pendidikan Islam. Jakarta: Bumi Aksara. 1996

Daradjat, Zakarya. Ilmu Pendidikan Islam. Jakarta: Bumi Aksara. 1992.

- Pendidikan Islam dalam Keluarga dan Sekolah. Jakarta: Ruhama. 1995.

Djamarah, Syaiful Bahri. Prestasi Belajar dan Kompetensi Guru. Surabaya: Usaha Nasional. 1994.

Hamalik, Oemar. Pendidikan Guru Berdasarkan Pendekatan Kompetensi. Jakarta: Bumi Aksara. 2004.

Kunandar. Guru Profesional Implementasi Kurikulum Tingkat Satuan Pendidikan (KTSP) dan Sukses dalam Sertifikasi Guru. Jakarta: Rajawali Pers. 2010.

Lajnah Pentashihah Mushaf Al-Qur'an. Pendidikan, Pembangunan karakter, dan Pengembangan Sumber Daya Manusia. Jakarta: Aku Bisa. 2012

Mulyasa, E. Menjadi Guru Profesional Menciptakan Pembelajaran Kreatif dan Menyenangkan. Bandung: Rosdakarya. 2011.

Ni’am, Asrorun. Membangun Profesionalitas Guru. Jakarta: eLSAS. 2006.

Rosyada, Dede. Paradigma Pendidikan Demokratis: Sebuah Model Pelibatan Masyarakat dalam Penyelenggaraan Pendidikan. Jakarta: Prenada Media. 2004. 
Shihab, M. Quraish. Tafsir Maudu'I: Atas Berbagai Persoalan Umat. Bandung: Mizan. 2000 . Tafsir Al mishbah: Pesan, Kesan dan keserasian Al-Qur'an. volume 7. Jakarta: Lentera Hati. 2002. . Tafsir Al mishbah: Pesan, Kesan dan keserasian Al-Qur'an. volume 8. Jakarta: Lentera Hati. 2002. - Tafsir Al mishbah: Pesan, Kesan dan keserasian Al-Qur'an. Juz Amma. Volume 15. Jakarta: Lentera Hati. 2002. - Membumikan AL-Qur'an: Fungsi dan Peran Wahyu dalam Kehidupan Masyarakat. Bandung: Mizan. 2013.

Suparlan. Guru Sebagai Profesi. Yogyakarta: Hikayat Publisshing. 2006.

Syahidin, Menelusuri Metode Pendidikan dalam Al-Qur'an. Bandung: Alfabeta. 2009. 